\title{
WEB-BASED CONTRACTOR EVALUATION SYSTEM FOR MASS-HOUSING PROJECTS IN TURKEY
}

\author{
Gokhan Arslan \\ Department of Civil Engineering, Anadolu University, 26555 Eskisehir, Turkey \\ E-mail: gokhana@anadolu.edu.tr \\ Received 08 Jul. 2010; accepted 04 Mar. 2011
}

\begin{abstract}
Determining the most appropriate contractor for a construction project is a highly critical issue. Selecting the right contractor for the right job can significantly influence the overall project performance. In the selection process, construction clients have to know all financial, technical and general information about the contractors to determine the most appropriate one for the project. Within this context, clients should consider several criteria that may include quality of production, adequacy of technical staff and financial stability. In this study, a survey was carried out among 52 construction professionals working at the Public Housing Development Administration (PHDA) in Turkey. The objective of this survey is to examine the relative weights of the criteria that have been using by this owner in the construction contractor selection process. Afterwards, a web-based contractor evaluation system, WEB-CONTEST, by which the contractors can be evaluated based on a combined criterion, is proposed. The system facilitates the contractor selection process and enables the construction owner to select the most correct contractors for its relevant projects.
\end{abstract}

Keywords: construction industry, contractor selection, mass-housing projects, Turkey, web-based technology, WEBCONTEST.

\section{Introduction}

General contractors (GCs) play an important role in the success of construction projects. Success levels of these projects may depend on the philosophy of selecting "the right person for the right job" (Palaneeswaran, Kumaraswamy 2000). Correct selection of GCs can increase the overall success of a construction project. Since construction projects are getting more complex, the need for evaluating GC performance becomes more crucial. Although there are no generalized sets of rules in evaluating GCs, several factors such as quality of production, adherence to program, financial stability, and completion of work on time should be considered by the construction clients in the selection process (Shen et al. 2003).

Information technology applications in the construction industry have been recognized as highly essential for improving business performance (Nitithamyong, Skibniewski 2004). Therefore, using web-based technologies can significantly improve and facilitate the GC evaluation process. Especially, Internet-based technology has been recognized as the utmost tool to facilitate information transfer effectively and a collaborative working environment in construction projects (Nitithamyong, Skibniewski 2006; Ruikar et al. 2006). Information exchange can be performed effectively between the members of construction projects through the use of web-based applications. Thus, problems caused by geographic fragmentation can significantly be reduced (Zhu et al. 2001).

In this study, a survey was carried out among 52 construction professionals working at the Public Housing
Development Administration (PHDA) in Turkey. The aim of this survey is to examine the relative weights of the criteria that have been using by this owner in the construction contractor selection process. Then, a web-based contractor evaluation system called WEB-CONTEST by which the contractors can be evaluated based on a combined criterion is presented. Using this system, the construction owner can select the most appropriate GCs for the relevant projects, speed up the selection process and gain the advantage of saving time and cost during the bidding process.

\section{Contractor selection process in construction}

In the construction industry, the most frequently used method of selecting construction contractors is competitive bidding, in which the lowest bidder is awarded the contract (Hatush, Skitmore 1998). Bidding is a highly important process especially in international construction projects by which the companies aim to position themselves in the international construction market (Dikmen, Birgonul 2004). The amount of profit level is critically determined at this stage. Thus, preparing realistic and accurate bid proposals becomes a vital task for the GCs. On the other hand, preparing tender documents, evaluating bids, and awarding the contract to the winner of the bid are among the major duties of the client.

Bidding process requires a great deal of time and effort especially for complex projects. Thus, a systematic procedure should be followed to prepare bid proposals for such projects (Arslan et al. 2006). In a typical public 

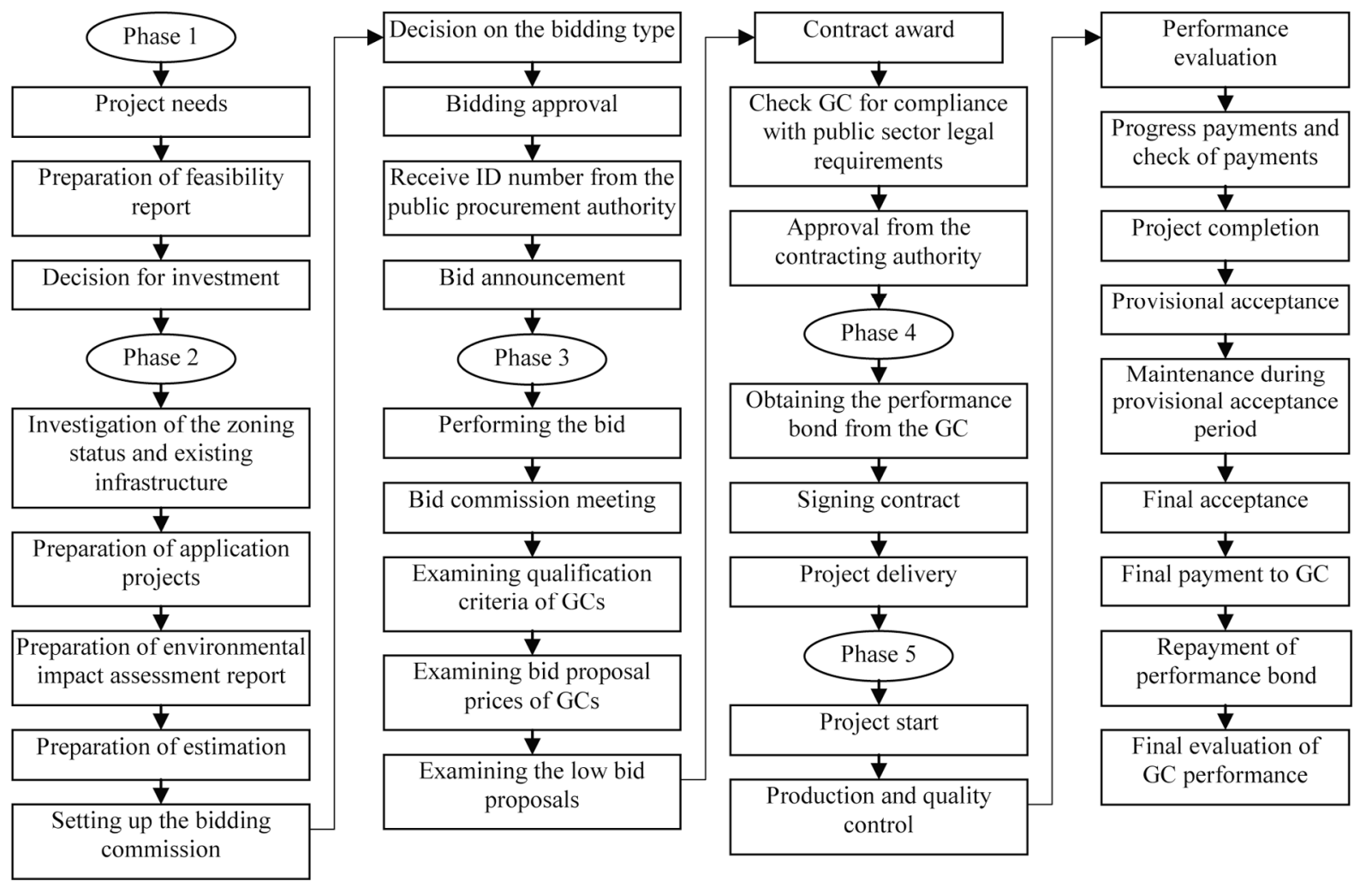

Fig. 1. Project delivery of a typical public construction project in Turkey

project in Turkey, the project delivery of a construction project including the bidding process is illustrated in Fig. 1. It should be noted that these phases are summarized according to the traditional approach of the bidding process. Some phases can change if latest technologies such as e-bidding will be used in this process. It should also be considered that any omitted item in these phases can cause delays or mistakes in the bidding process.

Public clients in Turkey are obliged to choose the contractor in agreement with the Public Procurement Law, which has been in effect since the $1^{\text {st }}$ of January 2003. According to this law, the tenderer with the economically most advantageous tender should be awarded the contract. In cases where it is not possible to determine the economically most advantageous tender on the basis of the lowest price only, the economically most advantageous tender is determined by taking into account the factors other than price such as operation and maintenance costs, cost-effectiveness, productivity, quality and technical merit. These factors must be stated in the tender documents and where possible, must be expressed in monetary values. Relative weights shall be determined in tender documents for the factors which cannot be expressed in monetary values. During the evaluation process, the tender commission determines the tenders that are abnormally low compared to the other tenders or the estimated cost determined by the contracting entity. Before rejecting these tenders, the commission requests from the tenderers the details relating to components of the tender that are determined to be significant. The tender commission then evaluates the abnormally low tenders taking into consideration the written explanations documented on the following aspects; economic nature of the manufacturing process, the service provided and the method of works; selected technical solutions and advantageous conditions to be utilized by the tenderer in supply of the goods and services or fulfilment of the works; and the originality of the goods, services or works proposed. After this evaluation, the tenders of the tenderers whose written explanations are found insufficient or who fail to make a written explanation are rejected.

In Turkey, although the public clients take into account the factors other than price, awarding the contract to the contractor with the lowest bid price is a common practice. According to Hatush and Skitmore (1998), public clients tend to select a contractor with the lowest bid price because they necessarily have to be accountable for their decisions and this becomes more difficult when selecting bidders other than the lowest. In private construction projects, clients generally develop their own procedures for selecting contractors (Singh, Tiong 2005). However, the lowest bid price is usually the key determinant factor in many countries for selecting GCs in public projects (Mahdi et al. 2002; Fong, Choi 2000; Topcu 2004). In Lithuania, the lowest bidder is selected as in Saudi Arabia, Canada and the USA (Zavadskas et al. 2008; Darvish et al. 2009; Banaitiene, Banaitis 2006). In Italy, Portugal and South Korea only the highest and the lowest applicants are excluded and the one closest to the average is selected (Darvish et al. 2009). The lowest price is also the main criterion to select a contractor in Poland. In 2007 , over $90 \%$ of public clients in Poland selected contractors with the lowest bid price (Plebankiewicz 2010). Competitive bid price has a critical role in award- 
ing a contract. However, depending on the lowest bid price alone may result in serious money losses for construction clients in the long run (Sönmez et al. 2002). As Hatush and Skitmore (1998) stated, contractor selection based solely on the lowest bid price is one of the major reasons for project delivery problems in the construction industry. It is relatively easy for the contractors to enter into this industry but many of them do not have the necessary expertise to complete the work satisfactorily ( $\mathrm{Ku}-$ maraswamy, Matthews 2000). Thus, inappropriate GCs that do not have required qualifications to carry out the work satisfactorily can be awarded the contract through this kind of selection practices.

Singh and Tiong (2005) defined contractor selection as "the process of selecting the most appropriate contractor to deliver the project as specified so that the achievement of the best value for money is ensured". Selecting qualified GCs can give confidence to clients that the selected GC can achieve the project goals (El-Sawalhi et al. 2007). Therefore, construction clients must be extremely careful while selecting the most appropriate GC for the project (Arslan et al. 2006). They have to be fair and objective in their relations with GCs. Poor selection of GCs may lead to the elimination of qualified GCs from business or result in poor quality work (Shash 1998). Construction clients may also loose time, moral and money by selecting unqualified GCs for the relevant projects. A simplified GC selection during the bidding process is illustrated in Fig. 2. It should be noted that the evaluation criteria shown in Fig. 2 are transparent and communicated to the bidding contractors.

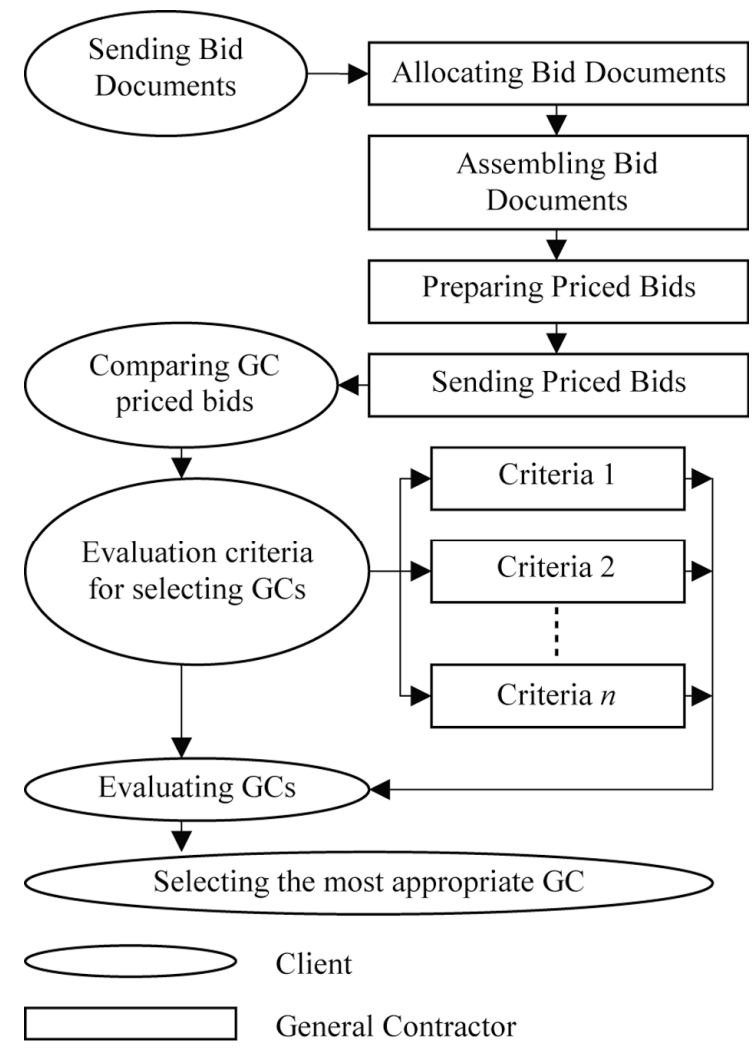

Fig. 2. Simplified contractor selection during bidding process
Selecting GCs without a systematic approach can generally cause problems in quality of work, delay in project duration and create additional costs in construction projects. Hence, traditional methods in GC selection may not usually meet the needs of construction projects. Construction clients should therefore consider not only the bid price of the GCs but also several criteria such as past business experience, financial stability and quality of products. This method of assessment can eliminate insufficient financed, inexperienced and incompetent GCs, reduce risks and contribute significantly to the overall success of the project. There have been no generalized sets of rules for contractor evaluation process. Construction clients should reduce expert's subjectivity in GC evaluation and it should be based on a combined assessment of various criteria. Thus, construction clients should implement a systematic evaluation process in the selection of the right GCs for the right job.

In traditional GC selection methods, clients generally tend to choose familiar GCs that had already done business with them.

Egemen and Mohamed (2005) showed that both clients and consultants have willingness to continue working with the same contractor in future projects if they are satisfied with the previous works. In the case of sub-contractor selections, the benefits and problems of this kind of selection practices have been highlighted by several researchers. Tserng and Lin (2002) pointed out the benefits of this kind of sub-contractor selection practices as flexibility, stability, mutual trust, decrease of transaction and search costs. On the other hand, difficulties in cost control and adoption of new technologies, and inefficiencies in sub-contractor selection and negotiation processes were some examples of the problems stated in their study. These benefits and problems may also be valid for GC selections.

\section{Previous studies in contractor selection methods}

There have been numerous studies in the literature on contractor selection methods. Methods have been proposed using approaches such as grey theory (Zavadskas et al. 2010), fuzzy set theory (Singh, Tiong 2005), evidential reasoning (Sönmez et al. 2002), multicriteria utility theory models (Hatush, Skitmore 1998), decision criteria (Russell, Skibniewski 1988), and linear programming (Elazouni, Metwally 2000). Rahman and Kumaraswamy (2004) showed the importance of relational, trust and jointresponsibility-related factors for selecting different parties. Palaneeswaran and Kumaraswamy (2000) focused on developing a model for contractor prequalification and bid evaluation in design \& build projects. Moreover, Jaselskis and Russel (1992), Crowley and Hancher (1995), Russel (1996), Kumaraswamy (1996) and Alsugair (1999) have identified commonly used criteria for prequalification and bid evaluation and have proposed methodologies for contractor selection. Alarcón and Mourgues (2002) proposed a contractor selection system that incorporates the contractor's performance prediction as one of the criteria for selection. A conceptual model that helps to identify information needed for a comprehensive evaluation was developed and 
used for the proposed contractor selection system. Russell and Skibniewski (1990) developed QUALIFIER-1, a computer program to aid decision makers in prequalification. Then, Russell et al. (1990) developed QUALIFIER-2 by adding some extra functions to QUALIFIER-1.

Holt et al. (1993, 1994a-d, 1995) provided example applications of multi-attribute analysis for evaluating construction bidders. Furthermore, Holt (1998) reviewed and analyzed the use of different contractor selection methodologies and discussed both the advantages and disadvantages of these methods. Shen et al. (2003) developed a computer-aided decision support system for assessing contractor's competitiveness. They also carried out some case studies to demonstrate the application of the system. Lam and Palaneeswaran (2009) presented an overview of potential suitability of Support Vector Machine (SVM) method for contractor/consultant prequalification in construction projects and proposed a SVMbased decision support framework. In their study, Juan et al. (2009) proposed a hybrid approach combining fuzzy set theory and quality function deployment to establish a housing refurbishment contractor selection model. They also tested the effectiveness of the proposed model by a multiple criteria decision-making method known as PROMETHEE to compare the results of contractor selections. Mahdi et al. (2002) developed a multi-criteria decision support system for contractor selection. They used the analytic hierarchy process (AHP) to assess the specific project conditions. Darvish et al. (2009) showed how the graph theory and matrix methods may be served as a decision analysis tool for contractor selection. Yasamis et al. (2002) developed a contractor quality performance (CQP) evaluation model that can be used in a contractor prequalification and/or selection system. Lahdenperä (2009) developed a multi-target competition process with special emphasis on the allocation algorithms that allow selecting the most qualified competitors for parallel follow-up competitions from among a large group of candidates.

Plebankiewicz (2009) proposed a model based on fuzzy sets theory. The model takes into consideration both different criteria of contractor evaluation and the objectives the construction owner wants to achieve in the project. Bendaña et al. (2008) also developed a fuzzylogic-based system for selecting contractors. Plebankiewicz (2010) investigated the methods and criteria for construction contractor selection, used by Polish public and private clients. According to the results of this study, public clients in Poland use just one of the criteria used to qualify a candidate to the second stage of tendering procedure and it is usually the contractor's experience.

Zavadskas et al. (2008) proposed a model that is based on a multi-attribute evaluation of contractors, the determination of their optimality criterion values according to Hodges-Lehmann rule. Zavadskas and Vilutienè (2006) presented a model that describes the process of selecting dwelling maintenance contractors. The model is based on a multi-criteria evaluation of maintenance contractors, the determination of their utility level for the building's users and a bid price in negotiations that are made according to the results of the multiple criteria analysis. Furthermore, Zavadskas et al. (2009) demonstrated the concept of general contractor choice on the basis of multiple attributes of efficiency with fuzzy inputs applying COPRAS-G method. Brauers et al. (2008) used the MOORA method that is based on ratio analysis and dimensionless measurement to accomplish the job of ranking the contractors in a non-subjective way. They made an application among the largest maintenance contractors of dwellings in Lithuania. In their study, Straub and van Mossel (2007) focused on contractor selection and quality assurance for performance-based maintenance projects and partnerships. They introduced VGO KEUR (Quality Mark for Real Estate Maintenance) that guarantees principals that contractors are able to work according to performance-based methods and procedures.

Besides contractor selection methods, there have also been several studies for sub-contractor selection (Ulubeyli et al. 2010). Kumaraswamy and Matthews (2000) showed how partnering principles can be profitably applied to the subcontractor selection process. Albino and Garavelli (1998) proposed a neural network application to support management in subcontractor rating. Tserng and Lin (2002) developed an integrated XML (eXtensible Markup Language) of Accelerated Subcontracting and Procuring (ASAP) model. They developed a web-based decision support system for GCs in order to decide an appropriate trade-off between risk and profit for different combinations of subcontractors. Vilutienè (2008) aimed to find the way for efficient monitoring and control of subcontractor performance in large construction projects, and proposed the procedure for recording and processing the nonconformities. Ko et al. (2007) developed a model called Sub-contractor Performance Evaluation Model (SPEM). In their study, an Evolutionary Fuzzy Neural Inference Model (EFNIM) is adapted as a learning and inference engine to execute the assessment process.

The author of this study has developed web-based systems to improve the bidding (EBPPS) and subcontractor selection (WEBSES) processes in construction. EBPPS was developed to reduce the bid proposal preparation time and cost in the bidding process (Arslan et al. 2006). On the other hand, WEBSES enables GCs to select the most appropriate sub-contractors for their relevant sub-works. It was designed as a web-based system by which the sub-contractors can be evaluated based on a combined criterion (Arslan et al. 2008). The system was also implemented in a GC company and the benefits of this system were discussed.

As seen from the literature, there are different evaluation tools and methods proposed for contractor selection in construction. These studies have significantly improved the GC selection process in the construction industry. However, some of these proposed methods and systems are practically difficult to apply and operate by construction professionals who need a learning process to understand and use such methods and systems. Arslan et al. (2008) stated that using complex, computational and mathematical models might not be effective in contractor selections. Bendaña et al. (2008) also indicated that some techniques 
such as the fuzzy-set theory could seem too complex to be accepted by the industry. WEB-CONTEST, the proposed system in this study, is a feasible tool to aid in decisionmaking for GC selection. The important characteristics of this system are its practical usage, easiness to learn and simplicity. It can help to make the GC evaluation process less complex and less time consuming. In addition, although the PHDA has currently been using several criteria for GC evaluation, there is a lack of a web-based system in this public administration for this selection process. Therefore, WEB-CONTEST has also the potential to facilitate the GC selection process of PHDA. The design of WEBCONTEST has similarities with that of WEBSES such as practical usage and simplicity. However, WEB-CONTEST is designed particularly for the PHDA and is adapted in this public administration to facilitate the GC selection process in mass-housing projects.

\section{The survey}

In this study, a survey was conducted at the PHDA of Turkey. PHDA has been operating in the housing sector and is the single responsible public body in this sector in Turkey. It contributes to the supply of housing in Turkey and provides housing especially for the low and middleincome groups. Building, promoting and supporting construction of housing units in locations where disasters take place; supporting the industry related to housing construction or those who are involved in this field; and establishing companies related with housing sector or participating in those that have already been established are some of the duties of this administration.

PHDA meets about $10 \%$ of the housing need in Turkey. The administration had built over 373 thousand houses on 1300 building sites and plans to reach 500 thousand by 2011 . It has 455 construction contractors in its database. A total number of 250 technical personnel have been employed in this organization. Moreover, 90 civil engineers have been employed at PHDA where 52 of them have been working at the main office. In GC selection for construction projects, PHDA has been using several evaluation criteria. These criteria can be categorized under the main headings as: quality, time, cost, and provisional / final acceptance. Each of these main headings contains sub-headings such as quality of subcontractors, timeliness in project approvals, and customer satisfaction. The objective of the survey was to determine the relative weights of these main and sub-criteria. Afterwards, these criteria and their relative weights are integrated into the proposed system, WEB-CONTEST, which is explained in the following section.

The survey was carried out during face-to-face interviews. All 52 construction professionals, including bid committee members, who have been working at the main office of PHDA are participated in this study. It was conducted over a two month period between August and September 2008. A survey questionnaire was administered during face-to-face interviews and it was divided into two main sections. Section 1 covered general information about the participants and section 2 dealt with the evaluation criteria. Simple Multi Attribute Rating Technique
(SMART) is used to determine the weights of the criteria. This technique is originally developed by Edwards (1971). In SMART, ratings of alternatives are assigned directly. In this method, the lowest level of criteria in the hierarchy is named as attributes instead of sub-criteria. Decision-makers are asked to rank each of the attributes, assigning the first ranked attribute to a score of 100 and the others a value between 0 and 100 depicting their ranked relationships (J. Kangas, A. Kangas 2005). Then the performance values with relative weights for all attributes are determined and a utility value for each alternative is calculated. One of the limitations of SMART is that it ignores the interrelationships between parameters. However, SMART is a useful technique since it is simple, less complex than some methods used in previous studies for determining the weights, straightforward and requires less time in decision making that is quite important for those involved in the decision-making process. In SMART, changing the number of alternatives will not change the decision scores of the original alternatives and this is useful when new alternatives are added (Valiris et al. 2005). Valiris et al. (2005) argued that using SMART in performance measures can be a better alternative than other methods.

Based on the results, $50 \%$ of the participants have more than 10 years' of experience in the construction industry. 18 out of 52 participants have 5-10 years' of experience and 8 participants have less than 5 years' of experience in the construction industry. The respondents were asked to evaluate the importance level of the main and sub-criteria. Fig. 3 illustrates the weights of the criteria as perceived by the respondents. According to the responses, quality was ranked as the first important criterion with a slight difference. On the other hand, provisional/final acceptance was ranked as the first criterion among the respondents having less than 5 years' of experience (Table 1). Moreover, time was considered as less important than other criteria among these participants. It was found that quality was ranked as the first criterion among the respondents having more than 5 years' of experience in the construction industry. Based on the evaluation of the subcriteria of quality, quality of production was considered as the most important criterion. Conformance to technical requirements and quality of materials used were determined as the following important criteria. Quality of subcontractors was considered as less important than expected since subcontractors play also an important role in the success of construction projects.

Table 1. Relative weights of main criteria according to experience of respondents

\begin{tabular}{cccc}
\hline & \multicolumn{3}{c}{$\begin{array}{c}\text { Weights according to experience of re- } \\
\text { spondents in construction sector }(\mathrm{yr})\end{array}$} \\
\hline Criteria & $\mathbf{0 - 5}$ & $\mathbf{5 - 1 0}$ & $>\mathbf{1 0}$ \\
\hline Quality & 0.2642 & 0.2609 & 0.2646 \\
\hline Time & 0.2226 & 0.2485 & 0.2410 \\
\hline Cost & 0.2453 & 0.2438 & 0.2478 \\
\hline $\begin{array}{c}\text { Provisional / Final } \\
\text { Acceptance }\end{array}$ & 0.2679 & 0.2468 & 0.2466 \\
\hline
\end{tabular}


CONTRACTOR EVALUATION

$\begin{array}{cccc}\text { Quality } & & \end{array}$

Fig. 3. Weights of main and sub-criteria

Similarly, the importance weights of the sub-criteria of time, cost and provisional / final acceptance are determined according to the responses. Adherence to programme was considered as the most important subcriterion of time whereas timely payment to labourers was ranked first in the evaluation of the sub-criteria of cost. Financial stability was considered as less important than expected. This criterion was found as one of the most important factors in contractor prequalification in the USA (Russell et al. 1992) and the UK (Holt 1998). Responsiveness to problems/maintenance and customer satisfaction are found as the most critical criteria for provisional/final acceptance, respectively. This result might be expected since the PHDA has been operating in the housing sector. Customer satisfaction in this sector is highly essential for both the owner and contractors to get success in this sector in the long run. As seen from Fig. 3, there are slight differences in relative weights between the criteria. The relatively negligible differences between the criteria show that the professionals considered all these criteria as highly important in contractor selections. The evaluation criteria and their relative weights are integrated into the proposed system, WEB-CONTEST, which is explained in the following section.

The survey results reflect the opinions of the technical personnel including bid committee members of PHDA. Based on the results, the criteria have also been almost equally weighted by these members. Thus, the results found in the survey also reflect the opinions of the bid committee members who make contract award decisions. However, the owner has the option to change the relative weights of the criteria depending on the demand and objectives of each project.

\section{Web-based contractor evaluation system (WEB-CONTEST)}

The main objective of developing WEB-CONTEST is to facilitate the GC selection process in construction projects of PHDA. In addition, it aims to minimize the problems that may occur in traditional selection processes as mentioned earlier. The system is designed as a web-based system to perform the evaluation process more effectively. As mentioned earlier, web-based technologies provide great advantages in performing business activities. Skibniewski and Abduh (2000) categorized the advantages of web technologies as; the support of relevant information services, communication between project participants, and engineering and management computing. The administration can evaluate GCs in a systematic manner by using this system. The evaluation process is based on a combined criterion including quality, time, cost and provisional/final acceptance as the main criteria. These criteria have been using by PHDA in contractor selections. However, the system provides flexibility for the PHDA in changing and adding criteria, and adjusting their weights. In order to facilitate the selection process and create a simple but effective selection method, WEB-CONTEST is designed as a simple and user-friendly system. 
ASP (Active Server Pages) is adopted as the programming language for WEB-CONTEST. MySQL, one of the most popular Open Source Databases, is used in this system. AJAX (Asynchronous JavaScript And XML) is used to create a faster and more interactive web application. It is based on JavaScript, XML (eXtensible Markup Language), HTML (Hyper Text Markup Language) and CSS (Cascading Style Sheets) open standards. HTML has major limitations such as extensibility, structure, and validation (Zhu et al. 2001). XML overcome these limitations by providing a more flexible and adaptable information identification (Zhu, Issa 2003). CSS is a language used to specify the layout or formatting properties of HTML elements. For this system, XHTML (eXtensible Hyper Text Markup Language) 1.1 validation is performed.

Every owner user can access to this system by using a password authorized by the owner, thus protecting the security of the system. Providing the password only to the users who will evaluate the GCs can also prevent the misuse of the system. However, only the administrator has the permission for making necessary updates and changes in the system. The main purpose of giving the responsibility to the administrator is to provide a systematic updating progress and prevent the misuse of the users. There are three different authorization levels in this system. Users in level 1 can only search GCs from the database and take necessary information. Users in level 2 can add and evaluate GCs additionally to user level 1 . Level 3 is the administrator level. Administration option consists of the following sub-options: user preferences, evaluation categories, contractors, contractor information, evaluation criteria and project types. The owner can evaluate GCs according to the evaluation criteria in the relevant options of the system. When adding new criteria by the administrator into the system, they can be assigned to one of the main criteria. Adding a criterion will cause a change in the weightings of the other criteria. However, this change is under the control of the administrator. In such conditions, the evaluation of the previously rated GCs will remain the same.

WEB-CONTEST consists of four options in the main menu including GC search, GC evaluation, user option and administrator option. Users can search GCs by the specialized areas of project types including housing, infrastructure, industrial, etc. GCs can be listed according to overall, cost, quality, time and provisional / final acceptance scores through the evaluation score option. An example of a GC search result according to the same project types (housing) is shown in Fig. 4. Users can also rank GCs according to evaluation scores on this web page.

\section{GC evaluation in WEB-CONTEST}

In GC evaluation option, users can evaluate GCs according to the sets of evaluation criterion which include quality, time, cost and provisional / final acceptance. Each of these main criteria contains sub-criteria as illustrated in Fig. 3. In Fig. 5, an example of a GC evaluation result is illustrated.
The first step of the evaluation is the quality criterion option. It includes the following sub-criteria: quality of materials used, quality of production, quality of subcontractors, adequacy of technical staff, and conformance to technical requirements. PHDA has been using these criteria to evaluate GCs' quality performance. Using materials according to the standards and a good standard of production during the construction phase are considered as critical performance criteria by PHDA. Moreover, having sufficient and qualified technical personnel of the GC can have a significant influence on the project success. Similarly, quality of subcontractors can also directly affect the project success. It should be noted that the owner can adjust the sub-criteria depending on the demand of each project. However, the selected sub-criteria should have a direct effect on performance. In addition, the selected evaluation criteria should also based on the measurement culture of the owner.

Each sub-criterion will be scored on a 1 to 10 scale, 1 being unsatisfactory and 10 being satisfactory. Then, GC's score will be calculated as a weighted sum of ratings over all sub-criteria, i.e., multiplication of each subcriterion by their weights. In this study, the weights found in the survey are integrated into the system. However, the system is flexible and the owner can set different weights for them depending on the demand of each project.

The sub-criteria of the quality option can be evaluated by the construction department of the owner since these criteria are more relevant to this department. Construction professionals having sufficient information about the GCs performance should make the evaluations. Performance evaluations without having sufficient information about the contractor can lead to inaccurate and unreliable evaluation scores. Therefore, this process should be under the control of the higher administration and system administrator. The construction department can also evaluate the criteria in time and provisional/final acceptance options whereas the estimating department can evaluate those of cost and time. An evaluation example of the quality option is shown in Fig. 6.

Further evaluation steps include time, cost and provisional/final acceptance options. Time criterion option consists of the following sub-criteria: timeliness in project approvals, timeliness in getting all permits, licenses and permissions, adherence to programme, completion of job on time, and timeliness in completing processes with government agencies. PHDA has been evaluating GCs' time performance using these criteria. Delays in project approvals and construction can have serious consequences for both the GC and owner. GCs can face with cash flow problems and possible liquidated damages. Thus, completion of job on time is critical for GCs and can improve the image of the company.

Cost criterion option consists of the following subcriteria: timely payment to labourers, timely payment of taxes and insurances, timely payment to material suppliers, timely payment to subcontractors, and financial stability. Delays in payments to labourers can cause serious problems such as demoralized workers. Similarly, late payments to subcontractors can also lead to poor project 
performance of the subcontractors. GCs need adequate cash flows to pay their workers and suppliers. If they do not receive prompt payments from the owner, they can face difficulties in payments to labourers, material suppliers and subcontractors. Thus, the progress of works can also be affected by GCs' financial strength that is considered as a critical criterion by PHDA.

PHDA has been using provisional/final acceptance criteria to evaluate GCs performance during the acceptance phases of the project. Provisional/final acceptance option consists of the following sub-criteria: provisional acceptance, final acceptance, customer satisfaction, responsiveness to problems/maintenance, and timeliness in submitting as-built plans. A provisional acceptance is a joint ascertainment of the works made immediately after the completion of the works. On the other hand, final acceptance is the act whereby the administrative authorities definitively appropriate the works alter having ascertained that the contractor has performed his obligations in their entirety. Customer satisfaction is a critical criterion for the administration since it has been operating in the housing sector. GC performance in responding to problems/maintenance during provisional and final acceptance period is also considered as an important criterion by PHDA. In provisional/final acceptance option, criteria such as 'responsiveness to problems/maintenance' and 'customer satisfaction' can be evaluated after completion of the project.

After completing the evaluation steps, the system calculates the overall score of the GC. Finally, the most appropriate $\mathrm{GC}$ can be selected based on the results of the evaluation scores. Depending only to overall scores may not always be the right way to choose the best GC. The owner may also consider the importance of the main criteria. A GC may get a higher overall score from other GCs. However, if one of the evaluation scores of main criteria is far lower than the other GCs, the owner may eliminate this GC. For example, Z\&U Construction can be awarded to contract as it has got the highest overall score (Fig. 4). However, the owner may also consider quality as the determinant factor in the selection. In such a case, Tech \& Tech Co. can be awarded the contract since it has got the highest evaluation score in the quality option (Fig. 4). Thus, the final decision for selecting a $\mathrm{GC}$ can be based on engineering judgment of the owner.

GCs will be evaluated by construction professionals after finishing the project. WEB-CONTEST will be updated after each GC evaluation. The number of evaluations depends on the number of projects that a GC has completed and the number of technical personnel who will evaluate the GCs.

A fair and objective evaluation should be performed by the users to avoid subjectivity. Objective evaluations are crucial for the effective usage of the system. Moreover, the evaluations of professionals who do not have adequate information about the GCs' performance can also result in inaccurate evaluation scores. Therefore, to overcome this problem, only those construction professionals who have enough information about the GCs' performance should make the evaluations. Obviously, this process should be under the control of the higher administration.

The relative weights used in evaluating GCs are not fixed for each project of PHDA. Each project can be different and can have different objectives. Thus, the owner can change the weights of the criteria according to the demands and priorities/objectives of the projects.

The administration can also consider weights of the criteria according to the experience of respondents. As Plebankiewicz (2010) stated, in prequalification it is important for the client to assign the right weights to the criteria. WEB-CONTEST provides the flexibility in changing the relative weights of the criteria.

WEB-CONTEST was tested at PHDA during a bidding process in August 2009. It was a small-sized construction project in the North-West region of Turkey. Two civil engineers tested the system. They evaluated GCs for the relevant project. Benefits of the system were realised in the selection process. These benefits could be summarized as follows:

- User-friendliness of the system;

- Faster selection process;

- Systematic approach for GC selection;

- Reduction of subjectivity in evaluation;

- Reduction in costs compared to traditional selection;

- Competitive bid proposal.

Although it is difficult to calculate the exact time saving of using this system, it is believed that it can significantly reduce the overall amount of time required for GC selection when compared the traditional approaches. Similarly, it is also difficult to estimate cost savings. However, this system can reduce paperwork's and requires less time for the selection process that can lead to reduction in costs. As a result, having past business records and immediate access to relevant information of GCs, it can significantly improve the selection process.

\section{Conclusions}

Selecting the right GC for the right job significantly influences the quality of work as well as the construction progress. Optimum selection of GCs is vital for the success of construction projects. Since construction projects have become more complex, a combined assessment of various criteria should be considered by the construction owners in order to select the most suitable one. Traditional GC selection methods can lead to poor project performance.

In this study, a survey was conducted at the PHDA which is the single responsible public body in the housing sector in Turkey. In this survey, the relative weights of the main and sub-criteria used by the administration in contractor selection are determined. Based on the survey results, quality was considered as the most important criterion by the administration. Although slight differences between the sub-criteria of quality were determined, quality of production seems to be the major criterion influencing the selection of contractors. Customer satisfaction was also found as an important criterion. 


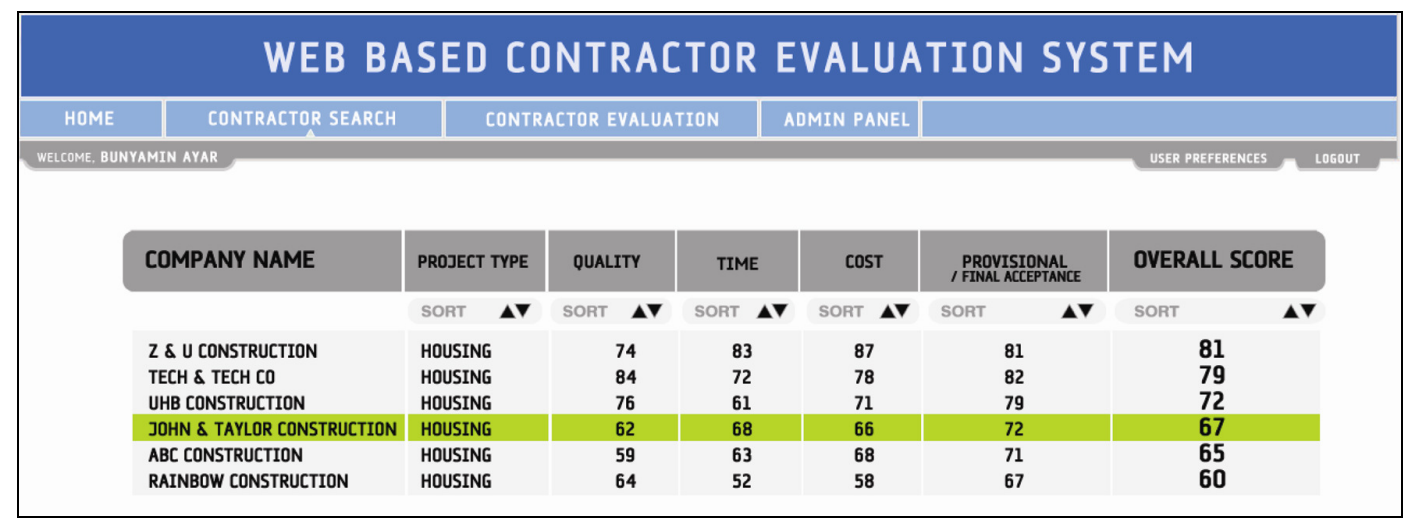

Fig. 4. An example of a GC search result

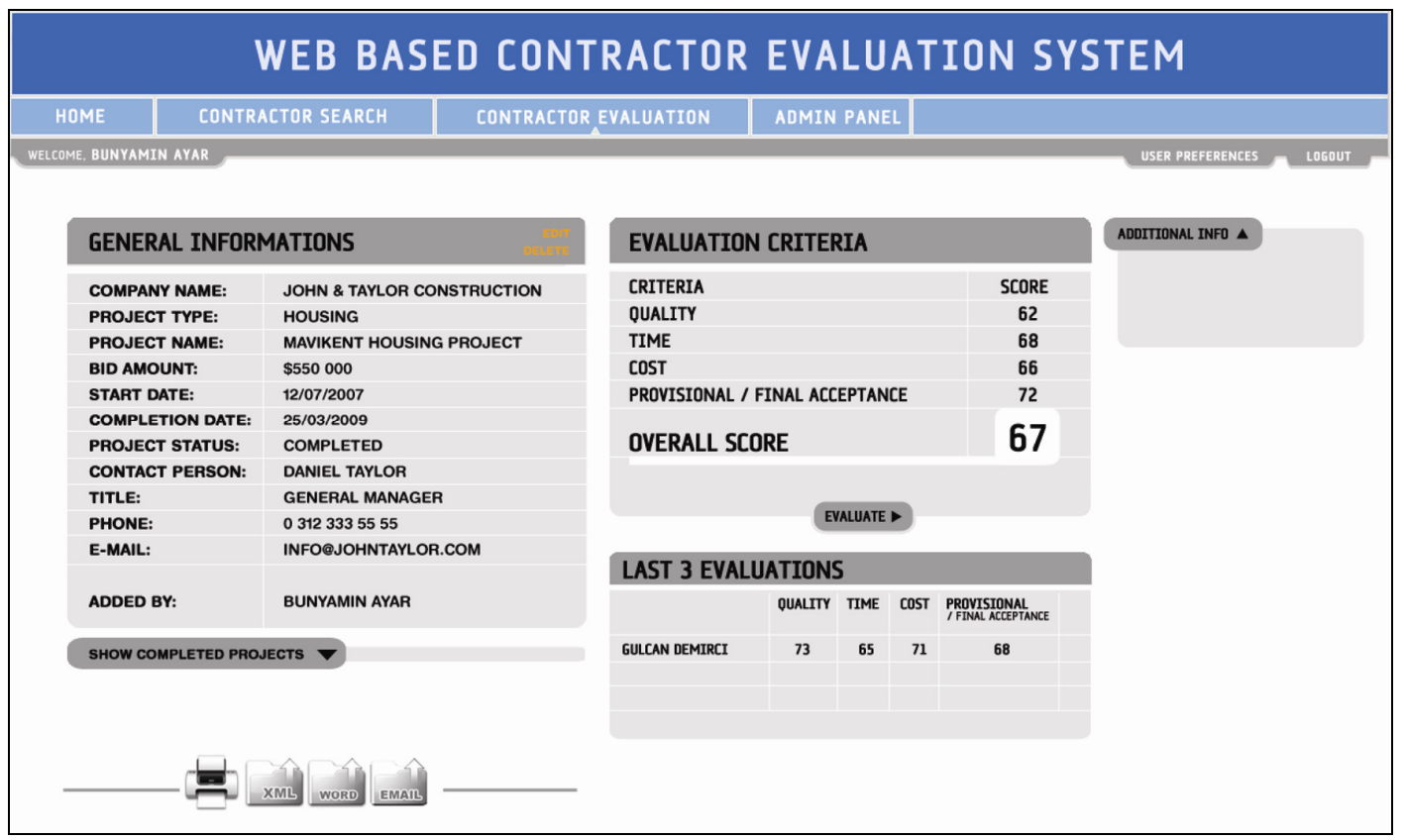

Fig. 5. An example of a GC evaluation result in WEB-CONTEST

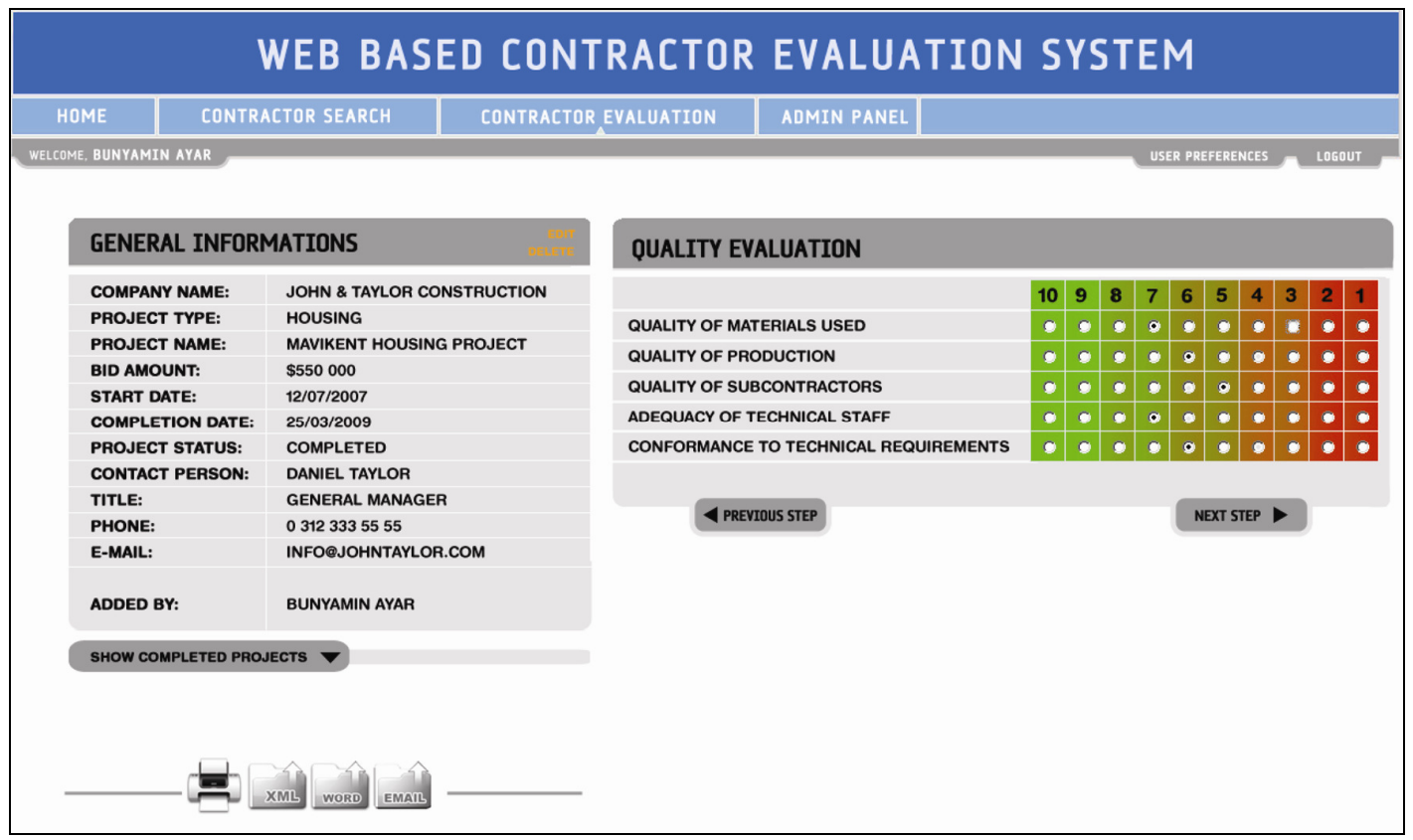

Fig. 6. Quality evaluation option 
These results might be expected since the PHDA has been operating in the housing sector. In this sector, the quality of the products and customer satisfaction can have a direct influence on the image and reputation of the administration. Having determined the relative weights of the criteria, these weights are then integrated into the proposed system.

The proposed system, WEB-CONTEST, can significantly facilitate the contractor selection process. WEBCONTEST can speed up the contractor selection process and improve the decision quality. It can ensure the elimination of lowest bid price dependence through evaluation of combined criterion and systematic approach. Objective evaluation with various criteria can lead to the elimination of unqualified GCs during the bidding process. Thus, sufficient, experienced and qualified GCs can be awarded to the projects. Problems caused by traditional GC selection methods can be eliminated. The system also provides flexibility in changing criteria and their weights. The applicability of the system was validated at PHDA during a bidding process of a construction project. Validation results show that the proposed system can significantly facilitate the GC selection process in construction projects.

The lowest bid price is also the determinant factor in the Turkish construction industry while selecting GCs for construction projects. Selecting GCs without evaluating necessary criteria also causes problems in construction projects in Turkey in the long run. Thus, this system can significantly facilitate the selection process in masshousing projects in Turkey. If properly done, GC evaluation through WEB-CONTEST can be an effective way in the selection of the correct GCs for mass-housing projects. Moreover, the system can be used for other types of real estate projects as well. The clients can also adapt the system in these projects to facilitate the contractor selection process.

\section{References}

Alarcón, L. F.; Mourgues, C. 2002. Performance modelling for contractor selection, Journal of Management in Engineering ASCE 18(2): 52-60. http://dx.doi.org/10.1061/ (ASCE)0742-597X(2002)18:2(52)

Albino, V.; Garavelli, A. C. 1998. A neural network application to subcontractor rating in construction firms, International Journal of Project Management 16(1): 9-14. http://dx.doi.org/10.1016/S0263-7863(97)00007-0

Alsugair, A. M. 1999. Framework for evaluating bids of construction contractors, Journal of Management in Engineering ASCE 15(2): 72-78. http://dx.doi.org/10.1061/ (ASCE)0742-597X(1999)15:2(72)

Arslan, G.; Tuncan, M.; Birgonul, M. T.; Dikmen, I. 2006. Ebidding proposal preparation system for construction projects, Building and Environment 41(10): 1406-1413. http://dx.doi.org/10.1016/j.buildenv.2005.05.024

Arslan, G.; Kivrak, S.; Birgonul, M. T.; Dikmen, I. 2008. Improving sub-contractor selection process in construction projects: Web-based subcontractor evaluation system (WEBSES), Automation in Construction 17(4): 480-488. http://dx.doi.org/10.1016/j.autcon.2007.08.004
Banaitiene, N.; Banaitis, A. 2006. Analysis of criteria for contractors' qualification evaluation, Technological and Economic Development of Economy 12(4): 276-282.

Bendaña, R.; del Caño, A.; de la Cruz, M. P. 2008. Contractor selection: fuzzy-control approach, Canadian Journal of Civil Engineering 35(5): 473-486. http://dx.doi.org/10.1139/L07-127

Brauers, W. K. M.; Zavadskas, E. K.; Turskis, Z.; Vilutiene, T. 2008. Multi-objective contractor's ranking by applying the MOORA method, Journal of Business Economics and Management 9(4): 245-255.

http://dx.doi.org/10.3846/1611-1699.2008.9.245-255

Crowley, L. G.; Hancher, D. E. 1995. Evaluation of competitive bids, Journal of Construction Engineering and Management ASCE 121(2): 238-245. http://dx.doi.org/10.1061/ (ASCE)0733-9364(1995)121:2(238)

Darvish, M.; Yasaei, M.; Saeedi, A. 2009. Application of the graph theory and matrix methods to contractor ranking, International Journal of Project Management 27(6): 610-619.

Dikmen, I.; Birgonul, M. T. 2004. Neural network model to support international market entry decisions, Journal of Construction Engineering and Management ASCE 130(1): 59-66. http://dx.doi.org/10.1061/(ASCE)07339364(2004)130:1(59)

Edwards, W. 1971. Social utilities, Engineering Economist, Summer Symposium Series 6: 119-129.

Egemen, M.; Mohamed, A. N. 2005. Different approaches of clients and consultants to contractors' qualification and selection, Journal of Civil Engineering and Management 11(4): 267-276. http://dx.doi.org/10.1080/13923730.2005.9636357

Elazouni, A. M.; Metwally, F. G. 2000. D-SUB: Decision support system for subcontracting construction works, Journal of Construction Engineering and Management 126(3): 191-200. http://dx.doi.org/10.1061/(ASCE)0733-9364 (2000)126:3(191)

El-Sawalhi, N.; Eaton, D.; Rustom, R. 2007. Contractor prequalification model: State-of-the-art, International Journal of Project Management 25(5): 465-474.

http://dx.doi.org/10.1016/j.ijproman.2006.11.011

Fong, P. S.-W.; Choi, S. K.-Y. 2000. Final contractor selection using the analytical hierarchy process, Construction Management and Economics 18(5): 547-557. http://dx.doi.org/10.1080/014461900407356

Hatush, Z:; Skitmore, M. 1998. Contractor selection using multicriteria utility theory: an additive model, Building and Environment 33(2-3): 105-115. http://dx.doi.org/10.1016/S0360-1323(97)00016-4

Holt, G. D. 1998. Which contractor selection methodology?, International Journal of Project Management 16(3): 153164. http://dx.doi.org/10.1016/S0263-7863(97)00035-5

Holt, G. D.; Olomolaiye, P. O.; Harris, F. C. 1993. A conceptual alternative to current tendering practice, Building Research \& Information 21(3): 167-172. http://dx.doi.org/10.1080/09613219308727284

Holt, G. D.; Olomolaiye, P. O.; Harris, F. C. 1994a. Factors influencing U.K. construction clients' choice of contractor, Building and Environment 29(2): 241-248. http://dx.doi.org/10.1016/0360-1323(94)90074-4

Holt, G. D.; Olomolaiye, P. O.; Harris, F. C. 1994b. Applying multi-attribute analysis to contractor selection decisions, European Journal of Purchasing \& Supply Management 1(3): 139-148. http://dx.doi.org/10.1016/0969-7012(94) 90003-5 
Holt, G. D.; Olomolaiye, P. O.; Harris, F. C. 1994c. Incorporating project specific criteria and client utility into the evaluation of construction tenderers, Building Research \& Information 22(4): 214-221. http://dx.doi.org/10.1080/09613219408727384

Holt, G. D.; Olomolaiye, P. O.; Harris, F. C. 1994d. Evaluating pre-qualification criteria in contractor selection, Building and Environment 29(4): 437-448. http://dx.doi.org/10. 1016/0360-1323(94)90003-5

Holt, G. D.; Olomolaiye, P. O.; Harris, F. C. 1995. Application of an alternative contractor selection model, Building Research \& Information 23(5): 255-264. http://dx.doi.org/10.1080/09613219508727473

Jaselskis, E. J.; Russell, J. S. 1992. Risk analysis approach to selection of contractor evaluation method, Journal of Construction Engineering and Management ASCE 118(4): 814-821. http://dx.doi.org/10.1061/(ASCE)0733-9364 (1992)118:4(814)

Juan, Y.-K.; Perng, Y.-H.; Castro-Lacouture, D.; Lu, K.-S. 2009. Housing refurbishment contractors selection based on a hybrid fuzzy-QFD approach, Automation in Construction 18(2): 139-144. http://dx.doi.org/10.1016/j. autcon.2008.06.001

Kangas, J.; Kangas, A. 2005. Multiple criteria decision support in forest management - the approach, methods applied, and experiences gained, Forest Ecology and Management 207(1-2): 133-143. http://dx.doi.org/10.1016/j.foreco.2004.10.023

Ko, C.-H.; Cheng, M.-Y.; Wu, T.-K. 2007. Evaluating subcontractors performance using EFNIM, Automation in Construction 16(4): 525-530.

http://dx.doi.org/10.1016/j.autcon.2006.09.005

Kumaraswamy, M. M. 1996. Contractor evaluation and selection-a Hong Kong perspective, Building and Environment 31(3): 273-282.

http://dx.doi.org/10.1016/0360-1323(95)00044-5

Kumaraswamy, M. M.; Matthews, J. D. 2000. Improved subcontractor selection employing partnering principles, Journal of Management in Engineering 16(3): 47-57. http://dx.doi.org/10.1061/(ASCE)0742-597X(2000)16: $3(47)$

Lahdenperä, P. 2009. Phased multi-target areal development competitions: Algorithms for competitor allocation, International Journal of Strategic Property Management 13(1): 1-22. http://dx.doi.org/10.3846/1648-715X.2009. $13.1-22$

Lam, K. C.; Palaneeswaran, E.; Yu, C.-Y. 2009. A support vector machine model for contractor prequalification, $A u$ tomation in Construction 18(3): 321-329. http://dx.doi.org/10.1016/j.autcon.2008.09.007

Mahdi, I. M.; Riley, M. J.; Fereig, S. M.; Alex, A. P. 2002. A multi-criteria approach to contractor selection, Engineering, Construction and Architectural Management 9(1): 29-37.

Nitithamyong, P.; Skibniewski, M. J. 2004. Web-based construction project management systems: how to make them successful?, Automation in Construction 13(4): 491-506. http://dx.doi.org/10.1016/j.autcon.2004.02.003

Nitithamyong, P.; Skibniewski, M. J. 2006. Success/failure factors and performance measures of web-based construction project management systems: professionals' viewpoint, Journal of Construction Engineering and Management ASCE 132(1): 80-87. http://dx.doi.org/10.1061/ (ASCE)0733-9364(2006)132:1(80)
Palaneeswaran, E.; Kumaraswamy, M. M. 2000. Contractor selection for design/build projects, Journal of Construction Engineering and Management ASCE 126(5): 331339. http://dx.doi.org/10.1061/(ASCE)0733-9364(2000) $126: 5(331)$

Plebankiewicz, E. 2009. Contractor prequalification model using fuzzy sets, Journal of Civil Engineering and Management 15(4): 377-385.

http://dx.doi.org/10.3846/1392-3730.2009.15.377-385

Plebankiewicz, E. 2010. Construction contractor prequalification from Polish clients' perspective, Journal of Civil Engineering and Management 16(1): 57-64. http://dx.doi.org/10.3846/jcem.2010.05

Rahman, M. M.; Kumaraswamy, M. M. 2004. Potential for implementing relational contracting and joint risk management, Journal of Management in Engineering ASCE 20(4): 178-189. http://dx.doi.org/10.1061/(ASCE)0742597X(2004)20:4(178)

Ruikar, K.; Anumba, C. J.; Carrillo, P. M. 2006. VERDICT An e-readiness assessment application for construction companies, Automation in Construction 15(1): 98-110. http://dx.doi.org/10.1016/j.autcon.2005.02.009

Russell, J. S. 1996. Constructor prequalification-choosing the best contractor and avoiding constructor failure. New York: ASCE Publications. 193 p.

Russell, J. S.; Hancher, D. E.; Skibniewski, M. J. 1992. Contractor prequalification data for construction owners, Construction Management and Economics 10(2): 117135. http://dx.doi.org/10.1080/01446199200000012

Russell, J. S.; Skibniewski, M. J. 1988. Decision criteria in contractor prequalification, Journal of Management in Engineering ASCE 4(2): 148-164. http://dx.doi.org/ 10.1061/(ASCE)9742-597X (1988) 4:2(148)

Russell, J. S.; Skibniewski, M. J. 1990. QUALIFIER-1: contractor prequalification model, Journal of Computing in Civil Engineering ASCE 4(1): 77-90.

http://dx.doi.org/10.1061/(ASCE)0887-3801(1990)4:1(77)

Russell, J. S.; Skibniewski, M. J.; Cozier, D. R. 1990. QUALIFIER-2: knowledge-based system for contractor prequalification, Journal of Construction Engineering and Management ASCE 116(1): 157-171. http://dx.doi.org/10. 1061/(ASCE)0733-9364(1990)116:1(157)

Shash, A. A. 1998. Bidding practices of subcontractors in Colorado, Journal of Construction Engineering and Management ASCE 124(3): 219-225. http://dx.doi.org/10. 1061/(ASCE)0733-9364(1998)124:3(219)

Shen, L. Y.; Lu, W.; Shen, Q.; Li, H. 2003. A computer-aided decision support system for assessing a contractor's competitiveness, Automation in Construction 12(5): 577-587. http://dx.doi.org/10.1016/S0926-5805(03)00020-7

Singh, D.; Tiong, R. 2005. A fuzzy decision framework for contractor selection, Journal of Construction Engineering and Management ASCE 131(1): 62-70. http://dx.doi.org/ 10.1061/(ASCE)0733-9364(2005)131:1(62)

Skibniewski, M. J.; Abduh, M. 2000. Web-based project management for construction: search for utility assessment tools, in Proc. of INCITE 2000, Hong Kong Polytechnic University, Hong Kong, 2000, 56-77.

Sönmez, M.; Holt, G. D.; Yang, J. B.; Graham, G. 2002. Applying evidential reasoning to prequalifying construction contractors, Journal of Management in Engineering ASCE 18(3): 111-119. http://dx.doi.org/10.1061/(ASCE)0742597X(2002)18:3(111) 
Straub, A.; van Mossel, H.-J. 2007. Contractor selection for performance-based maintenance partnerships, International Journal of Strategic Property Management 11(2): 65-76. http://dx.doi.org/10.1080/1648715X.2007.9637561

Topcu, Y. I. 2004. A decision model proposal for construction contractor selection in Turkey, Building and Environment 39(4): 469-481.

http://dx.doi.org/10.1016/j.buildenv.2003.09.009

Tserng, H. P.; Lin, P. H. 2002. An accelerated subcontracting and procuring model for construction projects, Automation in Construction 11(1): 105-125. http://dx.doi.org/10.1016/S0926-5805(01)00056-5

Ulubeyli, S.; Manisali, E.; Kazaz, A. 2010. Subcontractor selection practices in international construction projects, Journal of Civil Engineering and Management 16(1): 4756. http://dx.doi.org/10.3846/jcem.2010.04

Valiris, G.; Chytas, P.; Glykas, M. 2005. Making decisions using the balance scorecard and the simple multi-attribute rating technique, Performance Measurement and Metrics 6(3): 159-171. http://dx.doi.org/10.1108/14678040510636720

Vilutienè, T. 2008. Automated processing of subcontractor work performance data to improve the quality control and support the subcontractor selection process, in Proc. of The $25^{\text {th }}$ International Symposium on Automation and Robotics in Construction (ISARC-2008), 26-29 June, 2008, Vilnius, Lithuania, 507-514.

Yasamis, F.; Arditi, D.; Mohammadi, J. 2002. Assessing contractor quality performance, Construction Management and Economics 20(3): 211-223.

http://dx.doi.org/10.1080/01446190110113693
Zavadskas, E. K.; Kaklauskas, A.; Turskis, Z.; Tamošaitienė, J. 2009. Multi-attribute decision-making model by applying grey numbers, Informatica 20(2): 305-320.

Zavadskas, E. K.; Turskis, Z.; Tamošaitienè, J. 2008. Contractor selection of construction in a competitive environment, Journal of Business Economics and Management 9(3): 181-187. http://dx.doi.org/10.3846/1611-1699.2008.9.181-187

Zavadskas, E. K.; Vilutienė, T. 2006. A multiple criteria evaluation of multi-family apartment block's maintenance contractors: I-Model for maintenance contractor evaluation and the determination of its selection criteria, Building and Environment 41(5): 621-632. http://dx.doi.org/10.1016/j.buildenv.2005.02.019

Zavadskas, E. K.; Vilutienè, T.; Turskis, Z.; Tamošaitienė, J. 2010. Contractor Selection for Construction Works by Applying SAW-G and TOPSIS Grey Techniques, Journal of Business Economics and Management 11(1): 34-55. http://dx.doi.org/10.3846/jbem.2010.03

Zhu, Y.; Issa, R. R. A. 2003. Viewer controllable visualization for construction document processing, Automation in Construction 12(3): 255-269. http://dx.doi.org/10.1016/S0926-5805(02)00089-4

Zhu, Y.; Issa, R. R. A.; Cox, R. F. 2001. Web-based construction document processing via malleable frame, Journal of Computing in Civil Engineering ASCE 15(3): 157-169. http://dx.doi.org/10.1061/(ASCE)0887-3801(2001)15:3 (157)

Gokhan ARSLAN. An associate professor in the Civil Engineering Department at Anadolu University, Turkey. His main fields of interest are construction management, project management, information technology in construction, e-business in construction, and health and safety in construction. 